\title{
Methods of construction quality issues elimination with use of modern technology.
}

\author{
Sebastian Dubas ${ }^{1, *}$, Jerzy Pasławski ${ }^{2}$ \\ ${ }^{1}$ Poznan University of Technology, Institute of Structural Engineering, Piotrowo 5 street, 60-965 Poznan, Poland \\ 2 Poznan University of Technology, Institute of Structural Engineering, Piotrowo 5 street, 60-965 Poznan, Poland
}

\begin{abstract}
.
The purpose of this article is to indicate possibility of improving quality in construction thanks to use of new technological solutions. A problem of poor construction defect management, low quality assurance expenses and significant defect costs has been defined. Proposal of quality management tools has been suggested. Article presents set of defects collected throughout construction inspections. Defects were analysed (FMEA), further proposal of quality improvement based on proactive approach with use of modern technology solutions and their estimated influence on risk analysis has been described. The article is summed up with conclusions.
\end{abstract}

\section{Introduction}

No one needs to be convinced that construction differs from any other field of economic activity. Many factors indicate that construction differs in relation to the typical production activity in many ways such as: bonding the product to the ground, relatively high unit cost of the product, unitary and often unique production, craft character of production, large direct labour inputs by employees, impact of the changing environment on the processes being implemented, unique composition of the construction project management team such as contracting authority and its inspector, general contractor and subcontractors, suppliers, designers (architect, structural engineer, industry specialists), etc. This specific characteristic of construction generate typical problems in quality management, such as:

- Problems with acquiring qualified staff and employees,

- Frequent conflict situations that enable abuse by shareholders of the construction process,

- Frequent distortions and changes in the conditions of implementation, which significantly changes situation and requires determination of responsibility and indication of restoration path - a return to the normal state,

- Long quality chains that, in the event of problems, make it difficult to determine causes and responsibilities of the parties.

Table 1. Difference between reactive and proactive quality management.

\begin{tabular}{|c|c|c|}
\hline & Reactive & Proactive \\
\hline 1 & $\begin{array}{c}\text { Problem is identified when in collision with } \\
\text { successor works. }\end{array}$ & $\begin{array}{c}\text { The potential problem is identified and checked } \\
\text { before proceeding to the next stage. }\end{array}$ \\
\hline 2 & Errors are being verified ad hoc. & $\begin{array}{c}\text { Checklists are prepared for staff at the } \\
\text { operational level to detect errors at the source. }\end{array}$ \\
\hline 3 & Quality is verified occasionally. & $\begin{array}{c}\text { Quality monitoring is a continuous process - in } \\
\text { real time. }\end{array}$ \\
\hline 4 & $\begin{array}{c}\text { Quality inspections take place on final stages of } \\
\text { works. }\end{array}$ & $\begin{array}{c}\text { Quality inspections take place immediately after } \\
\text { the completion of every stage of works. }\end{array}$ \\
\hline
\end{tabular}

As a result, in the quality management there are enormous opportunities to upgrade and improve construction processes. By analysing the typical stages of quality management development, from quality inspection through quality control, quality assurance, total quality management, we come to Quality 4.0 inspired by the Industry 4.0 concept. Recalling the first industrial revolution based on the introduction of steam, the second introducing new opportunities based on mass production, the third becoming foundation of the digital computer, it is worth pointing out the foundation of the fourth revolution, which are digital-physical systems. Increased use of sensors, mobile devices and wireless communication will enable even better quality improvement thanks to a change of approach from traditional - reactive to new: proactive. The essential features of this change are included in Table 1.

\footnotetext{
* Corresponding author: sebastian.dubas@put.poznan.pl
} 
Analysing the situation in quality management in various countries, such as Finland (Teravainen et al.) [12], Spain (Prado-Roman et al. 2018) [13], Nigeria (Eze et al.) [14] or the countries of south-eastern Europe (Vukomanovic et al.) [15] various problems specific to individual countries or industry may be identified. However, the proactive approach is undoubtedly a mutual element of quality engineering development in construction in many countries. Departure from the traditional approach may be based on the use of increasingly popular BIM technology (Lin et al.) [16], which seems to be a particularly favourable breakthrough from the point of view of highly digitally undeveloped domain, such as construction. But should companies implement this expensive and demanding well-trained technology staff? Is it possible to improve the quality by using simpler devices and methods before the general use of BIM in construction?

\section{Quality problems in construction}

Construction industry is struggling with great amount of human labour force and low level of automation and industrialization. The above in combination with a high level of detail and lack of repeatability contributes to generation of a significant number of errors. The education of staff takes a relatively long time in relation to the duration of investment, which is why the employees' experience and proper supervision from managerial staff count on the construction site. In the current state, these two factors affect quality directly, and shortages in any of them result in errors. This is because, no quality control costs are anticipated on planning stage of investment or funds for these activities are relatively low. Lack of budget for supervision is a direct cause of the reactive approach, in which quality is mentioned only when the results of activities do not meet basic requirements and their repair is necessary. Transition to proactive quality management is suggested, which can contribute to the minimization of errors with the help of modern technological solutions, as discussed in this work.

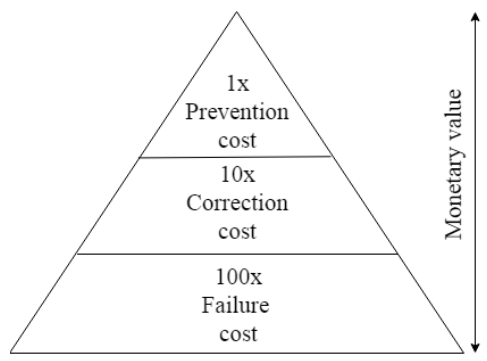

Fig. 1. Lack of quality costs, based on [10].

Severe influence of rework costs on construction companies profit, as revealed by Love et al. [11] (even $28 \%$ profit reduction) is a good starting point for proper quality management while planning investment. According to the approach explained by Ross and Perry [10] securing budget for quality assurance may produce income due to savings based on lack of rework and failure costs - it has been shown on monetary estimate example, according to which correction of errors costs 10 times more than their prevention, and what is more cost of failure is 100 times more than preventing it see fig. 1. Nevertheless defects are hard to anticipate, probability of occurrence is seldom known, impact is unpredictable, that is why it comes easily for decision makers to exclude or cut quality assurance costs form construction budget, because while planning it is hard to combine monetary value of quality management with final outcome of construction.

\section{Modern technology for quality management}

The computing power of modern computers and increasingly sophisticated software open up new possibilities for construction and quality management. Modern work tools are created, thanks to which design, construction, measurement, continuous and as-built quality control become faster and more accurate. Due to such progress, work expenditures on reactive activities are reduced, thus engineering and managerial staff can devote time to important issues such as proactive way of quality management.

Z. Ma et al. [1] showed collaborative system as a tool for quality management for purpose of on-site inspections. It consists of two main elements: 1) BIM model supplies visual form and digital description of designed elements while 2) indoor positioning system is responsible for locating inspector on construction site and simultaneously inspected elements in BIM model. Tool allows for double staged quality inspection. At first inspection is done by contractors inspector, after positive result of verification, system enables to invite inspector from supervisor for second stage of verification. During each inspection remarks concerning necessary repairs and rework are registered, saved on server and may be distributed among involved parties. System allows for making pictures, selecting target objects, assigning colours to BIM model elements representing whether inspected lot requires second stage of inspection (blue), passed inspection positively (green) or negatively (red). Ma et al. show that system based method of inspection is approximately $50 \%$ less time consuming than traditional method. 
In work dedicated to defect management with use of augmented reality, Lee et al. [2] present an approach to construction quality inspection with use of image matching technology that compares $3 \mathrm{D}$ model and view from camera. Translation visual data taken from camera allows to verify whether visible elements are arranged as supposed to be in designed model for purpose of quality check. What is more, simultaneous view of modeled information and view from camera is recommended for construction workers to allow them to see location, dimensions and size of elements to be built before actual works performance, what results in proactive quality management.

According to El-Saboni [4] research based on 2 case studies and series of interviews, electronic communication systems have positive effects on project in many areas. It is considered that improvement (how significant) occurred in such project success criteria as time (very high), quality (low), minimum variations (moderate), claim management (high), project team satisfaction (very high), master file with lessons learned (high).

Implementation of augmented reality (AR) in construction may be of use in construction quality management. Y. Zhou et al. [5] have studied feasibility of implementing AR into inspection of tunnelling works. Digital measurements have been investigated with use of camera, coordinates transformation program and marker as a base point for global coordinate determination. Inspection needs to be preceded by inspection planning, BIM model preparations and linking to markers.

Terrestial laser scanning (TLS) may be used in surface flatness measurements and may come helpful in quality control after works being performed (for example concrete flooring, earthworks and geodesy). According to F. Bosché and E. Guenet [6] accuracy of TLS measurements depends on chosen approach towards surface regularity calculation. From chosen methods (Straightedge and F-Numbers) they concluded that both can obtain satisfactory results in quality control, with possible better outcome after applying denser grid setup. What is important, with use of Straightedge approach achieved measurements were more precise and obtained in less time, comparing to traditional manual method. C. Boton et al. [7] performed case study on 4D BIM simulation in pre-construction and construction phases. Study resulted in showing that $4 \mathrm{D}$ simulation in construction phase can be of assistance in coordinating project, managing construction site, works and logistics. Usefulness of information gathered in BIM model depends on Level Of Development (LOD) of design. The higher LOD is helpful in analysing construction details. C. Boton [8] described VR-based 4D simulation preparation process with use of compact and portable simulation system, that may be utilised in on-going construction process.

\section{Defects throughout construction}

Construction projects characterize diversification of construction schemes, dimensions, spans, support elements, materials, organizational schemes, construction site, plot of ground, location etc. Due to unique and unrepeatable production, each construction faces many risks and is prone to defects. Construction engineers face quality issues and try to prevent defects arising on daily basis. Nevertheless, even with quality management plans and inspections some defects may occur. Case study has been based on list of sample defects collected throughout observations of numerous construction sites and inspections among constructions located in Poznan, Poland and its outskirts. From defect data collected, representative ones have been selected for purpose of further investigation. Defects assembled in Table 2 have diverse background. In presented case diversity of such criterion were juxtaposed:

- area of works during which defect occurred,

- type of defect and its consequence,

- cause and responsible phase of construction stage (design, construction),

- result and losses caused by defects,

- necessary actions required to solve problem,

Analyzing presented set of errors, one can notice basic division into designing and constructing errors. Love et al. [11] refer to them as project rework and construction rework. The former are mostly associated with processing of a large amount of information, which has to be coordinated in a multi-person team, and then conveyed in a descriptive and graphical form consisting of many interdependent drawings. Construction problems, on the other hand, characterize performance of unique works by construction workers (even within one field of works) in changing environmental conditions, and using a variety of materials characterized by diversified physical properties and applications, behaving differently under the influence of various factors. All of the above components contribute to the difficulties of performing works and are the reason for human errors at every stage of construction production. 
Table 2. Defects collation sheet.

\begin{tabular}{|c|c|c|c|c|c|c|c|c|c|c|}
\hline 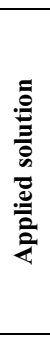 & 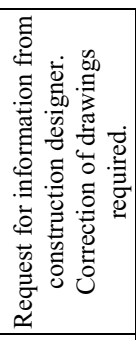 & 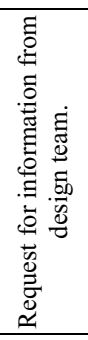 & 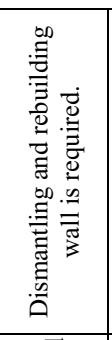 & 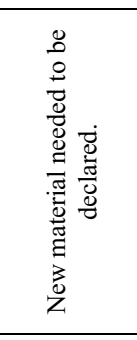 & 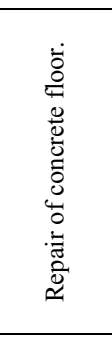 & 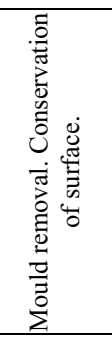 & 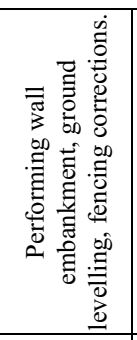 & 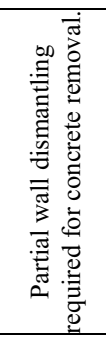 & 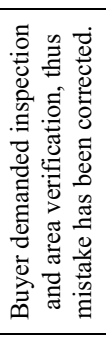 & 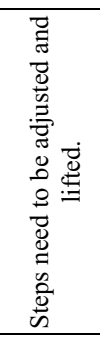 \\
\hline 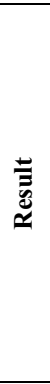 & 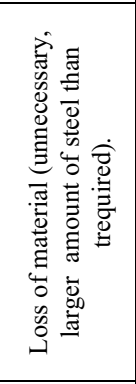 & 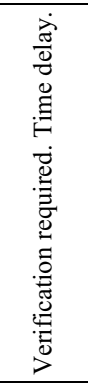 & 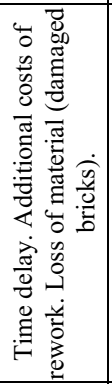 & 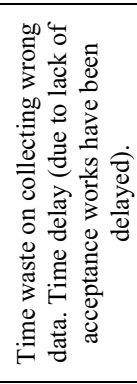 & 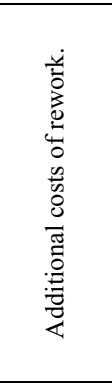 & 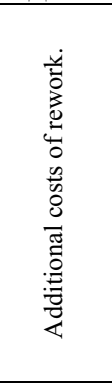 & 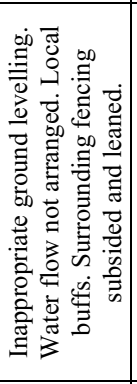 & 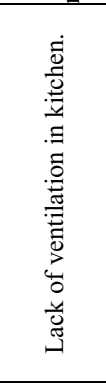 & 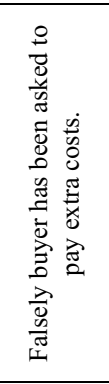 & 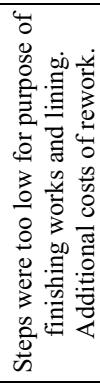 \\
\hline טֶ. & 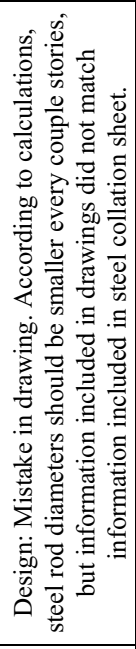 & 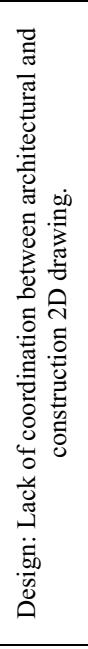 & 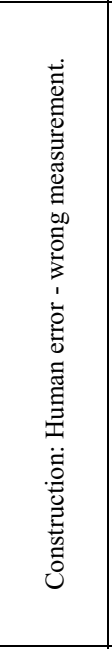 & 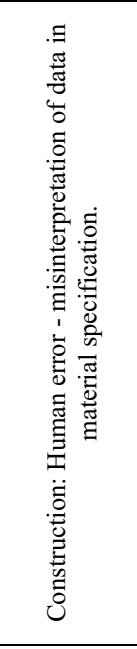 & 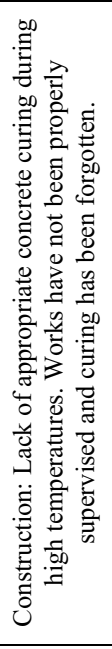 & 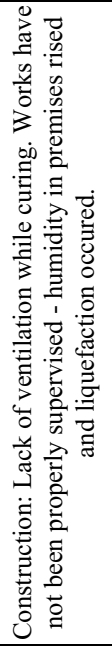 & 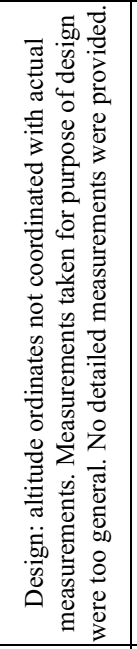 & 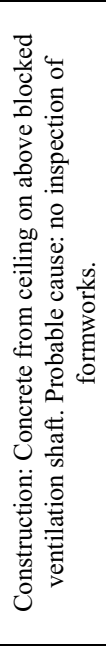 & 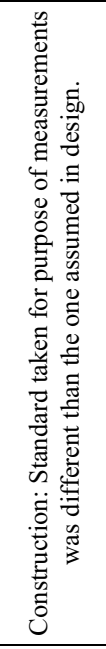 & 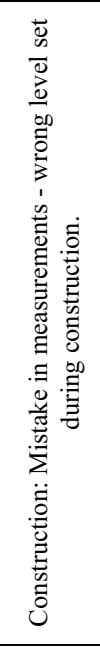 \\
\hline 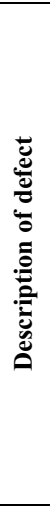 & 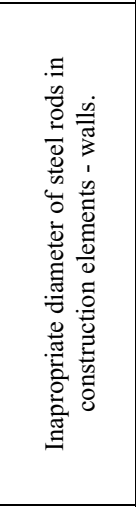 & 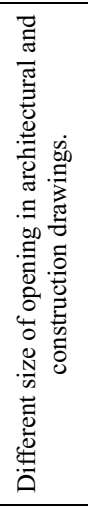 & 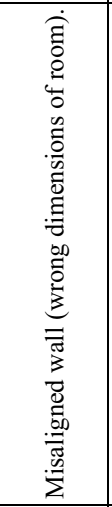 & 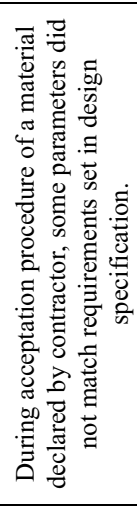 & 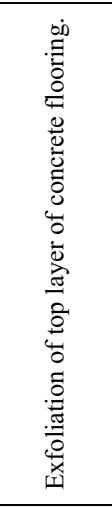 & 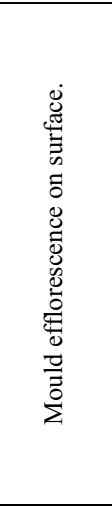 & 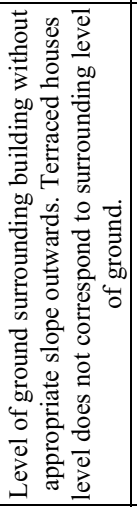 & 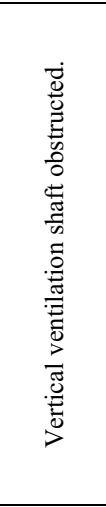 & 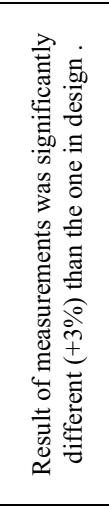 & 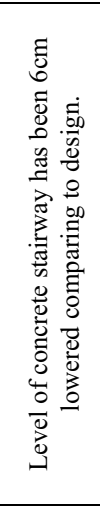 \\
\hline 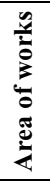 & 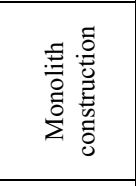 & 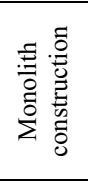 & 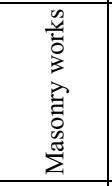 & 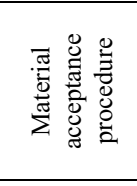 & 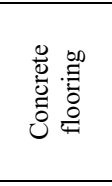 & 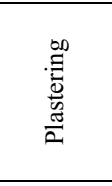 & 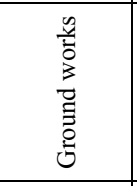 & 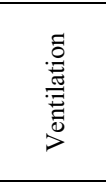 & 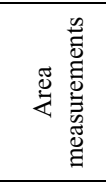 & 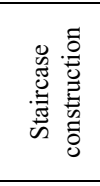 \\
\hline$\dot{z}$ & - & $i$ & $\dot{m}$ & $\dot{r}$ & in & $\dot{0}$ & $r^{\circ}$ & $\infty$ & $\sigma^{\circ}$ & $=$ \\
\hline
\end{tabular}




\section{Defects prevention with use of modern technology}

The defects shown in point 3. revealed in the course of works performance or inspection carried out, despite the differentiation of the origin areas and the divergent sources of their causes, have one thing in common. With the use of modern technological solutions, it would be possible to avoid their occurrence, reduce their severity or at least detect them faster.

The defect concerning monolithic structure and the incorrect diameters of reinforcing bars described in Table 2 was caused by a design error. As a proposition to avoid creating a mistake, it is possible to develop 3D documentation - BIM model with detailed information allowing such details as reinforcing steel class, diameter and length of relevant items to be included. With use of detailed documentation, table with set of the reinforcing steel would be made automatically and there would be no possibility of error and loss of information during the rewriting.

Another defect related to the incorrect dimensions between architectural and construction drawings was the cause of lack of inter-branch coordination. As in the previous case, when using the 3D BIM documentation, the defect would not have occurred, as the designer of a monolithic structure would have a direct picture of object's dimensions designed by the architect. In a situation in which, however, human error would occur, it could be detected quickly, still at the design stage, by means of the "clash detection" option between the models of individual industries.

The defect of the masonry structure, consisting in improper placement of the masonry wall in relation to the designed dimensions caused by a human error, would be possible to avoid using tools based on the Augmented Reality technology. Thanks to it, the contractor of the masonry structure would be able to visualize location of the wall in relation to the rest of the structure, thanks to which verification of dimensions would take place before the execution. In the event that the technology would not be introduced at the lowest level, but was only available to managers or inspectors, detection of the defect would be faster due to simple, unambiguous evaluation and comparison of reality with the project on common screen during the inspection.

Organizational and formal issues at the construction site can also lead to delays in implementation or defects (incorporation of inappropriate or non-compliant materials etc.). Building documentation contains a lot of data dispersed in many documents (drawing, descriptive), which should be combined in order to extract information about one element. To improve the construction process it would be necessary to merge descriptive documents (technical specification of performance and acceptance of works, technical description, etc.) with design drawings, which is practically achievable thanks to the use of 3D modeling and assigning parameters or references to individual elements. The implementation of detailed BIM project documentation, enriched with precise data on designed elements, materials and requirements, would allow to perform an automated statement of characteristics and a direct comparison of the proposed material in relation to the material being designed. In addition, contractor could easily send material inquiries to its suppliers, directly transferring all data available in the project.

\section{Analysis of possible defect prevention}

For purpose of establishing discussed defects influence on construction, a failure mode and effect analysis (FMEA) has been carried out twice. Evaluation has been made by 5 representatives of construction (average 9 years of experience). Each interviewee has been asked to evaluate each defect and assign score to an attribute. Presented scores reflect mean value out of all answers. Defects have been ranked according to attributes in given scale:

- Probability [P] - probability of occurrence according to scale: 1 - extremely unlikely, 2 - remote, 3 - occasional, 4 - reasonably possible, 5 - frequent,

- Severity [S] - severity of negative influence according to scale: 1 - no effect, 2 - very minor effect, 3 - minor effect, 4 - critical, 5 - catastrophic,

- Risk Level [RL] - score of multiplication probability by severity $[\mathrm{RL}]=[\mathrm{P}] \mathrm{x}[\mathrm{S}], \mathrm{RL}$ scale: $<9-$ low, $<12-$ moderate, $<15$ - high, $\geq 16$ - unacceptable.

Firstly defects have been evaluated as they are being handled currently on construction site. In second approach they were evaluated as predicted by construction staff, how would they be handled with use of modern solutions (partially explained in point 4 of this elaboration). It is worth noting that according to interviewees severity of defects have not been influenced by introduction of modern technologies. Results of two analysis are presented in table 3.

Performed FMEA analysis shows, that introducing new technologies into construction process, according to construction representatives, could help to diminish probability and increase detection of defects. As a result of proposed actions, risk level in 9 of 10 cases is predicted to be significantly lowered. Only in one case no technological novelty has been proposed. Due to specificity of ventilation obstruction defect, it would be hard to detect it with use of known visual aided tools because of superficial invisibility and inaccessibility of fault. Measurements of air flow or placing inspection camera in ventilation shaft would result in defect detection, which is how this defect has been detected in the first place. Nevertheless, as a result of interview, when asked about implementation of these measures into construction site, each representative noticed high cost of introduction as a barrier. 
Table 3. FMEA of introducing modern technology solutions for defect prevention.

\begin{tabular}{|c|c|c|c|c|c|c|c|c|c|c|c|}
\hline \multirow[b]{2}{*}{ No. } & \multirow{2}{*}{$\begin{array}{l}\text { Area of } \\
\text { works }\end{array}$} & \multirow{2}{*}{$\begin{array}{c}\text { Description of } \\
\text { defect }\end{array}$} & \multicolumn{4}{|c|}{ First risk analysis } & \multirow{2}{*}{$\begin{array}{l}\text { Introduced } \\
\text { solution }\end{array}$} & \multicolumn{4}{|c|}{ Second risk analysis } \\
\hline & & & {$[\mathbf{P}]$} & {$[\mathbf{S}]$} & {$[\mathbf{P}] \mathbf{x}[\mathbf{S}]$} & $\begin{array}{l}\text { Risk } \\
\text { Level }\end{array}$ & & {$[\mathbf{P}]$} & {$[\mathbf{S}]$} & {$[\mathbf{P}] \mathbf{x}[\mathbf{S}]$} & $\begin{array}{l}\text { Risk } \\
\text { Level }\end{array}$ \\
\hline 1. & $\begin{array}{l}\text { Monolith } \\
\text { construction }\end{array}$ & $\begin{array}{c}\text { Inapropriate } \\
\text { diamterer of steel } \\
\text { rods in } \\
\text { construction walls. }\end{array}$ & 4 & 3 & 12 & High & $\begin{array}{c}\text { BIM } \\
\text { modelling } \\
\text { with } \\
\text { construction } \\
\text { parameters }\end{array}$ & 1 & 3 & 3 & Low \\
\hline 2. & $\begin{array}{l}\text { Monolith } \\
\text { construction }\end{array}$ & $\begin{array}{l}\text { Different size of } \\
\text { opening in } \\
\text { architectural and } \\
\text { construction } \\
\text { drawings. }\end{array}$ & 4 & 5 & 20 & $\begin{array}{l}\text { Unacca } \\
\text { ptable }\end{array}$ & $\begin{array}{c}\text { BIM } \\
\text { modelling } \\
\text { with branch } \\
\text { coordination }\end{array}$ & 1 & 5 & 5 & Low \\
\hline 3. & $\begin{array}{l}\text { Masonry } \\
\text { works }\end{array}$ & $\begin{array}{l}\text { Misaligned wall } \\
\text { (wrong dimensions } \\
\text { of room). }\end{array}$ & 3 & 4 & 12 & High & $\begin{array}{l}\text { Augmented } \\
\text { Reality }\end{array}$ & 2 & 4 & 8 & Low \\
\hline 4. & $\begin{array}{l}\text { Material } \\
\text { acceptance } \\
\text { procedure }\end{array}$ & $\begin{array}{l}\text { During acceptation } \\
\text { procedure of a } \\
\text { material declared } \\
\text { by contractor, } \\
\text { some parameters } \\
\text { did not match } \\
\text { requirements. } \\
\end{array}$ & 4 & 5 & 20 & $\begin{array}{l}\text { Unacca } \\
\text { ptable }\end{array}$ & $\begin{array}{c}\text { BIM } \\
\text { modelling } \\
\text { with material } \\
\text { parameters }\end{array}$ & 2 & 5 & 10 & Moderate \\
\hline 5. & $\begin{array}{l}\text { Concrete } \\
\text { flooring }\end{array}$ & $\begin{array}{l}\text { Exfoliation of top } \\
\text { layer of concrete } \\
\text { flooring. }\end{array}$ & 4 & 5 & 20 & $\begin{array}{l}\text { Unacca } \\
\text { ptable }\end{array}$ & $\begin{array}{l}\text { 4D BIM } \\
\text { interactive } \\
\text { schedule }\end{array}$ & 2 & 5 & 10 & Moderate \\
\hline 6. & Plastering & $\begin{array}{c}\text { Mould } \\
\text { efflorescence on } \\
\text { surface. }\end{array}$ & 5 & 3 & 15 & $\begin{array}{l}\text { Unacca } \\
\text { ptable }\end{array}$ & $\begin{array}{l}\text { 4D BIM } \\
\text { interactive } \\
\text { schedule }\end{array}$ & 4 & 3 & 12 & High \\
\hline 7. & $\begin{array}{l}\text { Ground } \\
\text { works }\end{array}$ & $\begin{array}{l}\text { Level of ground } \\
\text { surrounding } \\
\text { building without } \\
\text { appropriate slope } \\
\text { outwards. }\end{array}$ & 2 & 5 & 10 & $\begin{array}{l}\text { Modera } \\
\text { te }\end{array}$ & $\begin{array}{c}\text { BIM } \\
\text { modelling } \\
\text { with scanning } \\
\text { input data }\end{array}$ & 1 & 5 & 5 & Low \\
\hline 8. & Ventilation & $\begin{array}{l}\text { Vertical ventilation } \\
\text { shaft obstructed. }\end{array}$ & 3 & 5 & 15 & $\begin{array}{l}\text { Unacca } \\
\text { ptable }\end{array}$ & $\begin{array}{l}\text { No modern } \\
\text { solution } \\
\text { proposed. }\end{array}$ & 3 & 5 & 15 & $\begin{array}{l}\text { Unaccap } \\
\text { table }\end{array}$ \\
\hline 9. & $\begin{array}{l}\text { Area } \\
\text { measure- } \\
\text { ments }\end{array}$ & $\begin{array}{c}\text { Result of } \\
\text { measurements was } \\
\text { significantly } \\
\text { different }(+3 \%) \\
\text { than the one in } \\
\text { design. }\end{array}$ & 3 & 4 & 12 & High & $\begin{array}{l}\text { BIM and } \\
\text { scanning }\end{array}$ & 2 & 4 & 8 & Low \\
\hline 10. & $\begin{array}{l}\text { Staircase } \\
\text { construction }\end{array}$ & $\begin{array}{c}\text { Level of concrete } \\
\text { stairway has been } \\
6 \mathrm{~cm} \text { lowered } \\
\text { comparing to } \\
\text { design. }\end{array}$ & 4 & 4 & 16 & $\begin{array}{l}\text { Unacca } \\
\text { ptable }\end{array}$ & $\begin{array}{l}\text { Augmented } \\
\text { Reality }\end{array}$ & 3 & 4 & 12 & High \\
\hline
\end{tabular}

\section{Summary and conclusions}

Until now, none of the developers on the Wielkopolska market has kept a digital record of defects [9], let alone comprehensive quality management or implementation of investments in BIM. Considering the planned late start of the implementation of BIM technology in Poland (the implementation horizon is estimated to be in 10 years), the question arises whether it remains only to accept errors in construction projects until then.

Analysis of the current situation in construction in our marketing environment, analysis of the case study and possible solutions, allows to draw the following conclusions: 
1. The most common cause of defects in construction is human error. This is the cause of many disadvantages which, in the face of complex implementation and design conditions, are difficult to avoid in the current form of conducting construction investments.

2. Low quality management expenditures cause a large number of re-processing costs and delays.

3. The inclusion of the FMEA method adapted to specifics of construction production may be the basis for systematic improvement of quality in construction processes.

4. Modern technologies are an excellent basis for improving the quality of construction projects, but the high cost of their implementation is a serious barrier to entry for both design and construction companies.

The authors see the possibility of a quick implementation of a simple and economically justified system that will streamline selected construction processes and support controlling activities to minimize defects and, above all, prevent them (proactive approach). The proposed solution can serve as a relatively quick improvement of current situation, and serve as a bridge between the current state of affairs and the future of the digital structure, which is the subject of further research.

\section{Acknowledgements}

The authors are grateful for supporting the research described in this paper from the statutory funds of the Institute of Structural Engineering of Poznan University of Technology 01/11/DSPB/0003.

\section{References}

1. Z. Ma, S. Cai, N. Mao, Q. Yang, J. Feng, P. Wang, Automat. Constr., Construction quality management based on a collaborative system using BIM and indoor positioning, 92, 35-45 (2018)

2. J.Y. Lee, J.So. Choi, O.S. Kwon, C.S. Park, 2012 International Conference on Information Science and Applications, A Study on Construction Defect Management Using Augmented Reality Technology, May 2012

3. A. Mills, P. E. D. Love, P. Williams, Journal of Construction Engineering and Management, Defect Costs in Residential Construction, January 2009

4. M. El-Saboni, G. Aouad, A. Sabouni, Advanced Engineering Informatics, Electronic communication systems effects on the success of construction projects in United Arab Emirates, 23, 130-138 (2009).

5. Y. Zhou, H. Luo, Y. Yang, Automat. Constr., Implementation of augmented reality for segment displacementinspection during tunneling construction, 82, 112-121 (2017).

6. F. Bosché, E. Guenet, Automat. Constr., Automating surface flatness control using terrestrial laser scanning and building information models, 44, 212-226 (2014).

7. C. Boton, S. Kubicki, G. Halin, Procedia Engineering, The Challenge of Level of Development in 4D/BIM Simulation Across AEC Project Lifecyle. A Case Study, 123, 59-67 (2015).

8. C. Boton, Automat. Constr., Supporting constructability analysis meetings with Immersive Virtual Reality-based collaborative BIM 4D simulation, 96, 1-15 (2018).

9. S. Dubas, J. Pasławski, Procedia Engineering, The concept of improving communication in BIM during transfer to operation phase on the Polish market, 208, 14-19 (2017).

10. J. E. Ross, S. Perry, Total Quality Management, CRC Press, (1999).

11. P. E. D. Love, Z. Irani, F. Ackermann, P. Teo, Production Planning and control, The cost of Rework: Insights from Construction and Opportunities for Learning (2018).

12. V. Teravainen, J.M. Junnonen, S. Ali-Loytty, Construction Economics and Building, Organizational culture: Case of the Finnish construction industry, 18, 48-69, (2018).

13. C. Prado-Román, C. Mercado-Idoeta, C. Del Castillo Peces, J. Del Castillo Peces, Cuadernos de Gestion, The effects of implementing ISO 9001 in the Spanish construction industry, 18, 149-172, (2018).

14. E. C. Eze, J. E. Idiake, B. O. Ganiyu, Independent Journal of Management \& Production, Rework risks triggers in the nigerian construction industry: a view of built environment professionals, 9, (2018).

15. M. Vukomanović, M.M. Nahod, M. Radujkovic, Journal of Civil Engineering and Management, EFQM excellence model as the TQM model of the construction industry of southeastern Europe, 20, 70-81, (2014).

16. Y. Ham, K.K. Ham, J. J. Lin, M. Golparvar-Fard, Visualization in Engineering, Visual monitoring of civil infrastructure systems via camera-equipped Unmanned Aerial Vehicles (UAVs): a review of related works, 4, (2016). 